\title{
Non-Neuronal Cell-Conditioned Medium Regulates Muscarinic Receptor Expression in Cultured Sympathetic Neurons
}

\author{
Kelli E. Smith and John A. Kessler \\ Albert Einstein College of Medicine, Departments of Neurology and Neuroscience, Bronx, New York 10461
}

Regulation of muscarinic receptor expression was examined in cultured sympathetic neurons of the neonatal rat superior cervical ganglion. Receptor concentration was determined by measuring binding of the muscarinic antagonist 1-quinuclidinyl [phenyl-4- ${ }^{3} \mathrm{H}$ ] benzilate ( $\left.{ }^{3} \mathrm{H}-\mathrm{QNB}\right) .{ }^{3} \mathrm{H}-\mathrm{QNB}$ bound to one apparent class of noninteracting sites on sympathetic neuron membranes with a $K_{\mathrm{d}}$ of $\mathbf{2 8 . 9} \mathrm{pM}$ and a $B_{\max }$ of 2.91 $\mathrm{pmol} / \mathrm{mg}$ protein. Binding increased as a linear function of tissue protein and was saturable. The number of receptors per milligram protein increased approximately 6-fold during $16 \mathrm{~d}$ of culture, and receptor numbers were down-regulated by treatment with the agonist carbachol. These observations suggested that measurement of ${ }^{3} \mathrm{H}-\mathrm{QNB}$ binding would provide a reliable estimate of muscarinic receptor number on cultured sympathetic neurons. To determine whether nonneuronal cells produce soluble factors that influence muscarinic receptor expression, the effects of treatment with rat fibroblast-conditioned medium (RFCM) were examined. Exposure of sympathetic neurons to $50 \%$ RFCM resulted in a $57 \%$ decrease in muscarinic receptor numbers without a change in the apparent $\boldsymbol{K}_{\mathrm{d} .}$. The decrease in ${ }^{3} \mathrm{H}-\mathrm{QNB}$ binding in response to RFCM was dose-related, with a minimum dose of $15 \%$ RFCM required to observe a significant effect. In contrast to the carbachol-induced down-regulation, the reduction in binding after RFCM treatment was not prevented by atropine, indicating that the effect was not mediated by acetylcholine stimulation of muscarinic reseptors. Binding of ${ }^{125}$ I-alpha-bungarotoxin, which labels a nonfunctional membrane site distinct from nicotinic receptors, was not altered by treatment with RFCM, indicating the selectivity of the change in membrane muscarinic receptors. Moreover, RFCM treatment increased levels of the cholinergic biosynthetic enzyme, choline acetyltransferase. These observations suggest that the complement of receptors expressed by sympathetic neurons may be regulated by suluble factors produced by non-neuronal cells, and that transmitter and receptor phenotypes may both be regulated by factors produced by a single type of non-neuronal cell.

Developing neurons potentially may express any of a large number of transmitters and transmitter receptors, and the precise complement of traits actually expressed is influenced by neu-

\footnotetext{
Received June 18, 1987; revised Nov. 2, 1987; accepted Nov. 27, 1987.

We wish to thank Ms. Antoinette Barnecott for help in preparing the manuscript. K.E.S. was supported by NRSA Training Grant MH15788. The research was supported by NIH Grants 29778 and 20013 to J.A.K.

Correspondence should be addressed to Kelli E. Smith, Albert Einstein College of Medicine, 1300 Morris Park Avenue, Bronx, NY 10461.

Copyright (c) 1988 Society for Neuroscience $0270-6474 / 88 / 072406-08 \$ 02.00 / 0$
}

ronal interactions with the environment. For example, sympathctic neurons that in vivo exhibit predominantly noradrenergic traits synthesize and release acetylcholine when cultured in the presence of certain non-neuronal cells (Patterson, 1978). Moreover, medium conditioned by exposure to non-neuronal cells, such as fibroblasts, stimulates cholinergic traits, suggesting that transmitter expression may be regulated by non-neuronal cell-derived soluble factors (Patterson and Chun, 1977). Rat fibroblast-conditioned medium (RFCM) also stimulates levels of the neuropeptides somatostatin and substance $\mathbf{P}$ and their respective $\mathrm{mRNAs}$, indicating that multiple transmitter systems may be simultaneously regulated by soluble factors (Kremer and Kessler, 1986; Spiegel et al., 1986). Other environmental cues may also influence transmitter expression: cholinergic development is promoted in cultured sympathetic neurons by neuronal contact with cell membranes (Adler and Black, 1985; Kessler et al., 1986; Wong and Kessler, 1987), whereas noradrenergic differentiation is fostcred by depolarizing stimuli (Black et al., 1971; Walicke et al., 1977) or glucocorticoids (Patterson, 1978; Fukada, 1980; McLennan et al., 1980; S7e and Hedrick, 1983). Thus, multiple factors in the neuronal microenvironment may help determine transmitter phenotype.

Less is known about mechanisms regulating transmitter receptor expression, although it is apparent that the number of receptors expressed by cultured cells is influenced by environmental factors. For example, $\beta$-adrenergic receptor number in cultured fibroblasts (Pochet et al., 1982), hepatocytes (Nakamura et al., 1984), and astrocytoma cells (Harden et al., 1979) is regulated by cell density. Both the number and distribution of muscle acetylcholine receptors are regulated by soluble factors produced by CiNS tissue (Jessell et al., 1979; Schaffner and Daniels, 1982). In pancreatic acinar cells, the number of cholecystokinin receptors is stimulated by treatment with glucocorticoids (Logsdon, 1986), and in PC12 cells both nicotinic and muscarinic receptor numbers are elevated after nerve growth factor (NGF) treatment (Dichter et al., 1977; Jumblatt and Tischler, 1982; Amy and Bennett, 1983). Finally, transmitters themselves may down-regulate receptor number and alter (desensitize) receptor responsiveness (see Sibley and Lefkowitz, 1985).

Is neuronal receptor expression influenced by the same microenvironmental factors that influence transmitter development? To approach this question, we sought to examine the influence on sympathetic neuron receptor development of culture conditions known to regulate transmitter expression. Sympathetic neurons contain a variety of transmitter receptors, including nicotinic, muscarinic, substance $\mathrm{P}, \alpha$ - and $\beta$-adrenergic receptors, and others (Obata, 1974; Brown and Fumagalli, 1977; Brown and Caulfield, 1979; Brown et al., 1980; Ashe and Libet, 
1982; Kouvelas and Greene, 1982; Brown and Dunn, 1983; Ip and Zigmond, 1984; Ballanyi and Grafe, 1985; Brown and Selyanko, 1985; Ip et al., 1985; Niwa et al., 1985; Kiraly et al., 1986). The choice of receptor for study in culture required that it have a relatively high membrane density of receptors, an availability of a specific high-affinity ligand, and a demonstrable biologic function in vivo. The muscarinic receptor, for which the high-affinity ligand ${ }^{3} \mathrm{H}-\mathrm{QNB}$ is available, met all of these criteria. Muscarinic receptors on superior cervical ganglion (SCG) neurons participate in the ganglion response to acetylcholine released from preganglionic fibers. Preganglionic stimulation in the presence of nicotinic blocking agents results in slow excitatory and slow inhibitory postsynaptic potentials that are blocked by muscarinic antagonists (Ashe and Yarosh, 1984; Cole and Shinnick-Gallagher, 1984). Moreover, direct activation of receptors with muscarinic agonists stimulates a variety of biochemical and physiological responses in the isolated rat SCG (Hashiguchi et al., 1982; Bone et al., 1984; Brown and Selyanko, 1985; Cahill and Perlman, 1985; Horwitz et al., 1986). Consequently, we examined the regulation of muscarinic receptors in cultured sympathetic neurons. Alpha-bungarotoxin ( $\alpha$-BTX) binding sites, which are present in the SCG but have no known function, were measured as a control for nonspecific changes in neuronal cell membranes. We report that RFCM, which promotes cholinergic transmitter expression, significantly reduces muscarinic receptor number, suggesting that transmitter and receptor traits in sympathetic neurons may both be regulated by the neuronal microenvironment.

\section{Materials and Methods}

Materials. Tissue culture media, penicillin, streptomycin, trypsin, and fetal bovine serum were obtained from Gibco. NGF was prepared in our laboratory according to the method of Mobley et al. (1976). Cytosine- $\beta$-D-arabinofuranoside (Ara C), atropine, carbachol, oxotremorine, muscarine, hexamethonium, and nicotine were purchased from Sigma Chemical Company (St. Louis, MO). Pirenzipine was the kind gift of Karl Thomae, W. Germany.

Experimental animals. Pregnant Sprague-Dawley rats (CAMM) were housed in clear plastic and wire cages and were exposed to 650-800 lux of cool white illumination from 5 AM to 7 PM daily. Ralston Purina lab chow and water were offered ad libitum. Neonates were routinely used within $24 \mathrm{hr}$ after delivery, and were killed by a blow to the head immediately prior to the removal of the SCG.

Tissue culture techniques. SCGs from neonatal rats were treated with trypsin $(0.1 \%)$, mechanically dissociated, and plated on a rat-tail collagen substratum, as previously described (Kessler et al., 1984). Growth medium consisted of Ham's nutrient mixture F12 with $10 \%$ heat-inactivated fetal bovine serum (F12FCS10), NGF $(100 \mathrm{ng} / \mathrm{ml})$, penicillin $(50 \mathrm{U} / \mathrm{ml})$, and streptomycin $(50 \mu \mathrm{g} / \mathrm{ml})$. Cultures were maintained at $37^{\circ} \mathrm{C}$ in a humidified $95 \%$ air $/ 5 \% \mathrm{CO}_{2}$ atmosphcre. Ganglion non-neuronal cells were eliminated by treatment with Ara $C(5 \mu \mathrm{M})$ on days 1 and 3 of culture. Cultures were fed 3 times/week; experimental treatments were begun on day 2 with the first feeding and were continued for a total of 14 to $16 \mathrm{~d}$ before harvesting.

Preparation of rat fibroblast-conditioned medium. Skin samples from embryonic rats (E17) were treated with trypsin, mechanically dissociated, and plated on tissue culture plastic in Eagle's minimal essential medium containing $15 \%$ fetal bovine serum. Fibroblasts were allowed to grow to confluence in this medium, which minimized the survival of other cell types; at the first passage, the feeding medium was switched to F12FCS10 so that it could be used to treat neuronal cultures. Medium collected from confluent cultures (RFCM) was filtered $(0.45 \mu \mathrm{m}$; Millipore) and mixed with various percentages of fresh medium for treatment of SCG cultures. Unused RFCM was storcd at $-20^{\circ} \mathrm{C}$.

Preparation of tissue from cultured SCG neurons. Neuron numbers in each culture were determined by counting representative areas, as previously described (Kessler, 1985). Cultures were rinsed in ice-cold assay buffer ( $40 \mathrm{~mm}$ sodium/potassium phosphate, $\mathrm{pH}$ 7.4) and har- vested by scraping with a rubber policeman into a small volume of buffer. Samples were homogenized with a Polytron (Brinkman; setting $51 / 2,10 \mathrm{sec})$ and collected by centrifugation at $4^{\circ} \mathrm{C}(39,000 \times \mathrm{g} ; 15 \mathrm{~min})$. The pellets were washed twice and resuspended in ice-cold assay buffer at approximately $100 \mu \mathrm{g}$ protein $/ \mathrm{ml}$, and were kept cold until use that day. Protein was determined by the method of Bradford (1976).

Muscarinic binding assay. Binding assays were carried out in $40 \mathrm{~mm}$ sodium/potassium phosphate, $\mathrm{pH} \mathrm{7.4}$, at $25^{\circ} \mathrm{C}$ for $1 \mathrm{hr}$. Varying concentrations of 1 -quinuclidinyl [phenyl-4- ${ }^{3} \mathrm{H}$ ] benzilate ( ${ }^{3} \mathrm{H}-\mathrm{QNB} ; 30-46$ $\mathrm{Ci} / \mathrm{mmol}$; Amersham) were incubated with $\sim 10 \mu \mathrm{g}$ tissue protein in a total volume of either 1 or $2 \mathrm{ml}$ in $12 \times 75 \mathrm{~mm}$ glass tubes. Nonspecific binding was determined in the presence of $1 \mu \mathrm{M}$ atropine. Incubation was terminated by rapid filtration (Cell Harvester, Brandel) over GF/B glass-fiber filters (Whatman), followed by rinsing with $3 \times 5 \mathrm{ml}$ of icecold assay buffer. Filters were placed in scintillation vials and were allowed to sit overnight in $10 \mathrm{ml}$ scintillation cocktail (Hydrofluor; National Diagnostics) before being counted in a Packard liquid-scintillation counter at $50-55 \%$ efficiency.

$\alpha-B T X$ binding assay. Tissue from SCG cultures was prepared as described, except that samples were collected and homogenized in PBS ( $10 \mathrm{~mm}$ sodium/potassium phosphate, $145 \mathrm{~mm} \mathrm{NaCl}$ ), $\mathrm{pH} 7.4$. Binding assays were carried out in PBS, pH 7.4 containing $0.1 \%$ BSA at $25^{\circ} \mathrm{C}$ for $3 \mathrm{hr}$. ${ }^{125} \mathrm{I}-\alpha$-BTX was incubated with $\sim 50 \mu \mathrm{g}$ tissue protein in $12 \times$ $75 \mathrm{~mm}$ polypropylene tubes in a total volume of $250 \mu \mathrm{l}$. The final concentration of ${ }^{125} \mathrm{I}-\alpha$-BTX was $5 \mathrm{nM}$; nonspecific binding was determined in the presence of $5 \mu \mathrm{M}$ unlabeled $\alpha$-BTX. Incubation was terminated by rapid filtration over GF/B filters presoaked in $0.1 \%$ polyethylenimine (PEI), followed by rinsing with $4 \times 5 \mathrm{ml}$ ice-cold assay buffer. Filters were counted immediately in a Packard Gamma Counter at $90-95 \%$ efficiency.

Data analysis. Data from saturation and inhibition curves were analyzed by computer, using a modification of the nonlinear least-squares regression program, LIGAND (Munson and Rodbard, 1980).

Enzyme assays. Details of enzymatic assays for choline acetyltransferase (CAT) and tyrosine hydrcxylase have been reported previously (Kessler and Black, 1979; Kessler, 1985).

\section{Results}

To define the characteristics of muscarinic receptors on cultured sympathetic neurons, the nonselective lipophilic muscarinic antagonist ${ }^{3} \mathrm{H}-\mathrm{QNB}$ was used as a radioligand in receptor binding assays. Saturation isotherms obtained by varying the concentration of the labeled ligand (Fig. 1) show that specific binding to washed homogenates of 2-week-old sympathetic ncuron cultures increased sharply between 0.01 and $0.1 \mathrm{nM}{ }^{3} \mathrm{H}-$ QNB and reached saturation at $0.5 \mathrm{nM}$, representing at least $75 \%$ of total binding at all concentrations tested. In contrast, nonspecific binding increased in a nonsaturable fashion that was linear with ${ }^{3} \mathrm{H}-\mathrm{QNB}$ concentration (Fig. 1). Scatchard transformation (Fig. 2) of the saturation data shown in Figure 1 reveals that ${ }^{3} \mathrm{H}-\mathrm{QNB}$ bound to one apparent class of noninteracting sites with a $K_{\mathrm{d}}$ of $28.9 \pm 2.4 \mathrm{pm}$ and a $B_{\max }$ of $2.91 \pm 0.6 \mathrm{pmol} /$ $\mathrm{mg}$ protein (mean $\pm \mathrm{SEM} ; n=6$ ), as determined by linear regression analysis. This low $K_{\mathrm{d}}$ value, corresponding to highaffinity binding, agrees well with published values for ${ }^{3} \mathrm{H}-\mathrm{QNB}$ binding to other membrane preparations (Nathanson, 1983). Specific binding of ${ }^{3} \mathrm{H}-\mathrm{QNB}$ increased as a linear function of tissue protein and remained linear up to a concentration of 35 $\mu \mathrm{g}$ protein $/ \mathrm{ml}$, the highest tested (Fig. 3), indicating that changes in specific binding are good estimates of changes in receptor concentration under these conditions.

The pharmacological specificity of the site was examined using various unlabeled drugs as inhibitors of ${ }^{3} \mathrm{H}-\mathrm{QNB}$ binding (Fig. 4). The selective muscarinic agonists oxotremorine and muscarine each inhibited ${ }^{3} \mathrm{H}-\mathrm{QNB}$ binding with an $\mathrm{IC}_{50}$ in the micromolar range (2.6 and $3.1 \mu \mathrm{M}$, respectively, with Hill coefficicnts $n_{\mathrm{H}}=0.7$ ), and the $\mathrm{IC}_{50}$ for the cholinergic agonist carbachol was $43 \mu \mathrm{M}\left(n_{\mathrm{H}}=0.4\right)$. In contrast to the muscarinic 


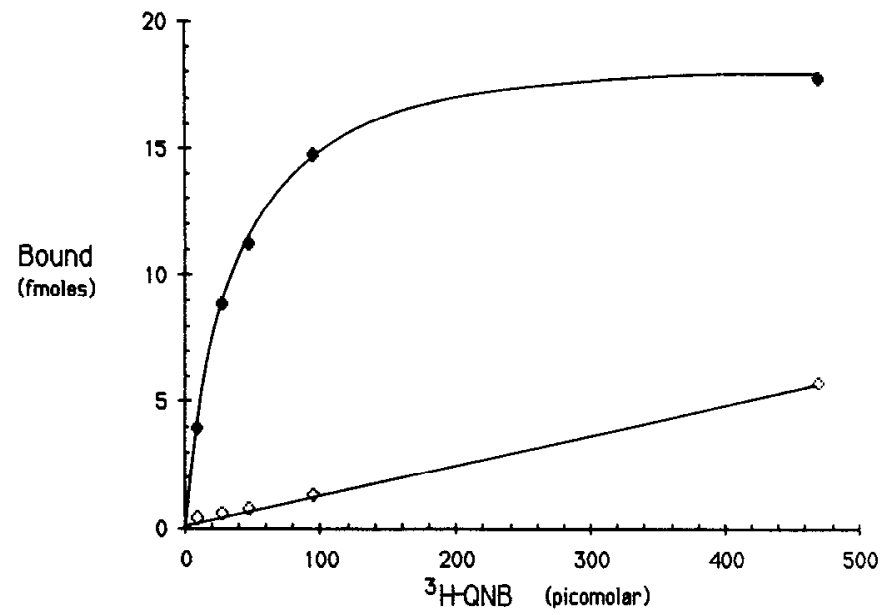

Figure 1. Saturation isotherm of ${ }^{3} \mathrm{H}-\mathrm{QNB}$ binding to a membrane preparation of cultured SCG neurons. Cultures were grown for 2 weeks before harvesting for ${ }^{3} \mathrm{H}-\mathrm{QNB}$ binding. Specific binding $(\diamond)$ was determined by subtracting nonspecific $(\diamond)$ from total. Each point was determined in triplicate; results are representative of those obtained in 6 separate experiments.

agonists, the nicotinic ligands nicotine and hexamethonium were much less potent $\left(\mathrm{IC}_{50} \mathrm{~s}=0.14\right.$ and $0.89 \mathrm{~mm}$, respectively), confirming the selectivity of QNB for muscarinic sites. The classical antagonist atropine (mean $\mathrm{IC}_{50}=7.6 \pm 1.0 \mathrm{nM}$; mean Hill coefficient, $1.01 ; n=2$ ) was a more potent inhibitor than pirenzipine, a selective $\mathrm{Ml}$ antagonist $\left(\mathrm{IC}_{50}=2.0 \pm 0.8 \mu \mathrm{M}\right.$; $n=2$ ). It is likely that a mixture of muscarinic receptor subtypes was present, since the Hill coefficient for pirenzipine was 0.8 .

To determine whether these muscarinic sites could be downregulated by exposure to agonist, as has been demonstrated in other systems (Siman and Klein, 1981; Champion and Mauchamp, 1982), cultures were treated with various doses of carbachol and assayed for ${ }^{3} \mathrm{H}-\mathrm{QNB}$ binding after 2 weeks. As shown in Figure 5, chronic treatment with carbachol resulted in a 55$65 \%$ decrease in muscarinic binding at doses above $1 \mu \mathrm{M}$.

The development of muscarinic binding with time in culture was examined (Fig. 6). Membrane protein levels increased steadily with time in culture, coincident with an observed pro-

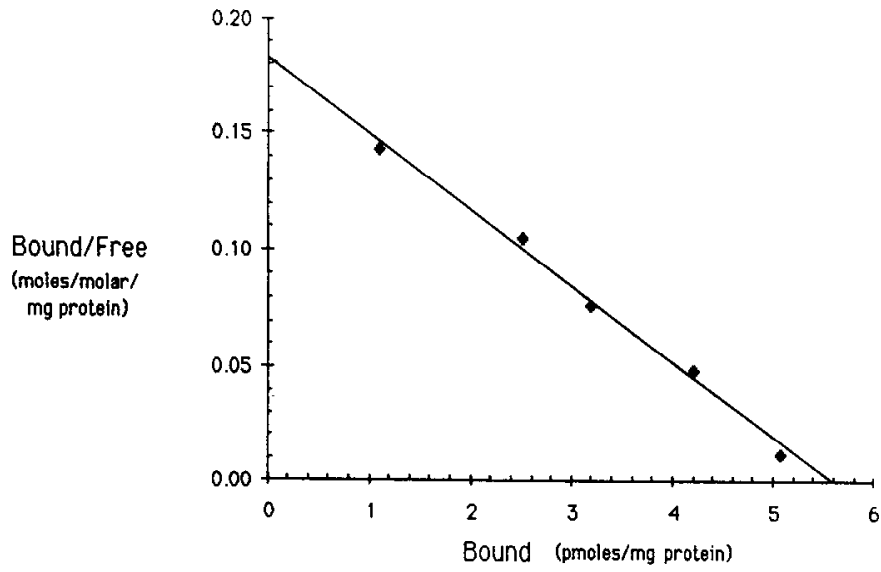

Figure 2. Scatchard analysis of saturation data from Figurc 1. Binding parameters were calculated by linear regression analysis after determining that a 1 -site model was appropriate. ${ }^{3} \mathrm{H}-\mathrm{QNB}$ binds to one apparent site with an average $K_{\mathrm{d}}=28.9 \pm 2.4 \mathrm{pM}$ and $B_{\mathrm{max}}=2.91 \pm 0.60 \mathrm{pmol} /$ mg protein (mean $\pm \mathrm{SEM} ; n=6)$.

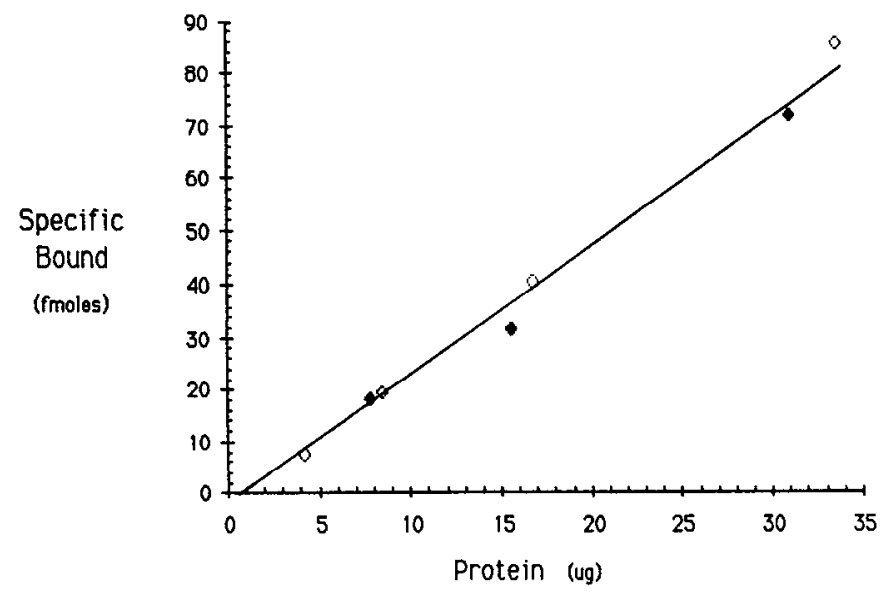

Figure 3. Specific binding of $0.5 \mathrm{~nm}{ }^{3} \mathrm{H}-\mathrm{QNB}$ as a function of tissue protein concentration. Cultures were grown for 2 weeks before harvesting. Varying amounts of protein were assayed for ${ }^{3} \mathrm{H}-\mathrm{QNB}$ binding. Graph represents 2 separate experiments, represented by different symbols. Solid line was determined by linear regression of combined data $(r=0.996)$.

liferation of neurites (data not shown). However, muscarinic binding increased more than 4-fold on a per-milligram protein basis between days 2 and 7 in culture, then increased proportionally with protein. The total number of receptors increased from $0.5 \mathrm{pmol} / \mathrm{mg}$ protein in the neonatal ganglion before culturing to $2.9 \mathrm{pmol} / \mathrm{mg}$ protein in $16 \mathrm{~d}$ pure neuronal cultures (Fig. 6).

\section{Effects of RFCM on muscarinic binding}

The transmitter phenotype of cultured sympathetic neurons depends on the physiologic state and environment of the neuron (Patterson, 1978; Black, 1982; Kessler et al., 1983). For example, culture of sympathetic neurons in the presence of RFCM promotes the expression of cholinergic traits (Patterson and Chun, 1977). To determine whether the receptor phenotype is also

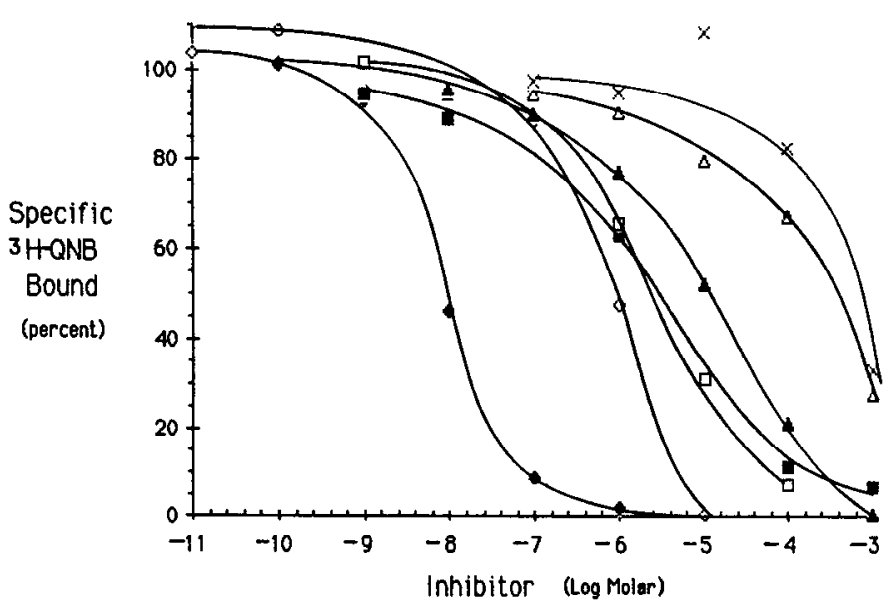

Figure 4. Inhibition of ${ }^{3} \mathrm{H}-\mathrm{QNB}$ binding by cholinergic ligands. SCG cultures were grown for 2-3 weeks before harvesting for indirect binding assays. Assays were performed using $0.5 \mathrm{~nm}{ }^{3} \mathrm{H}-\mathrm{QNB}$ with varying concentrations of the following inhibitors: atropine $(\bullet)$, pirenzipine $(\diamond)$, oxotremorine $(\square)$, muscarine $(\square)$, carbachol $(\Delta)$, hexamethonium $(\Delta)$, and nicotine $(x)$. Each curve was determined in triplicate. $\mathrm{IC}_{50} \mathrm{~s}$ and $n_{\mathrm{H}} \mathrm{s}$ (see text) were determined by nonlinear least-squares regression. 


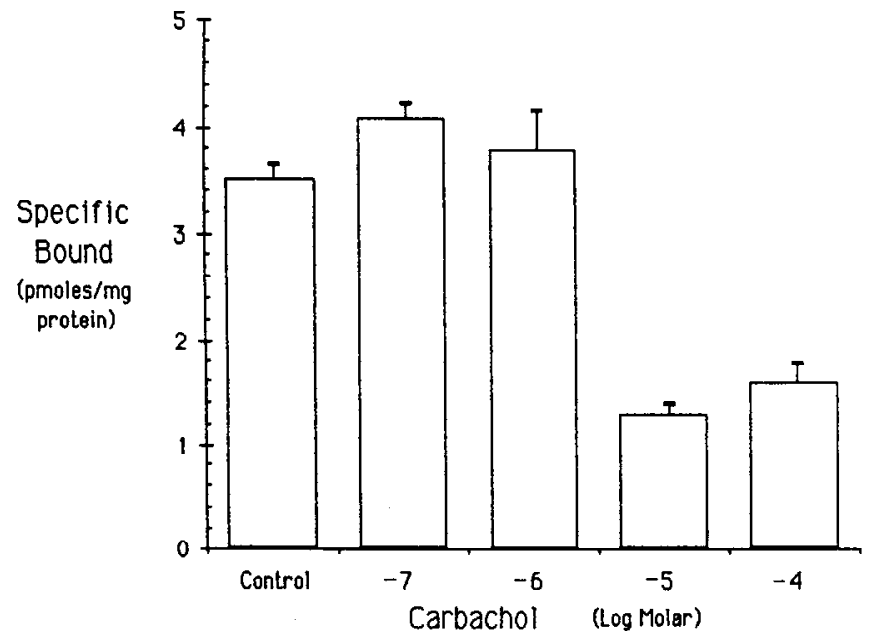

Figure 5. Effect of chronic carbachol treatment of SCG cultures on binding of $0.5 \mathrm{nM}^{3} \mathrm{H}-\mathrm{QNB}$. Cultures were treated for $16 \mathrm{~d}$ with various doses of carbachol before harvesting for ${ }^{3} \mathrm{H}-\mathrm{QNB}$ binding. Bars represent mean $\pm \mathrm{SD}$ of one representative experiment.

influenced by the environment, muscarinic binding of neurons cultured in the presence of RFCM was examined. Treatment of dissociated SCG neurons with $50 \%$ RFCM for 2 weeks resulted in a $57 \%$ decrease in specific ${ }^{3} \mathrm{H}-\mathrm{QNB}$ binding, from a mean of $1.31 \pm 0.14$ to $0.56 \pm .06 \mathrm{pmol} / \mathrm{mg}$ protein $(n=3$; Fig. 7$)$, with no significant change in neuron number. Figure 8 shows that RFCM inhibited binding in a dose-related fashion. The minimum dose of RFCM required to observe a significant effect was $15 \%$, and the concentration required to inhibit half the binding was approximately $40 \%$.

To determine whether the decrease in binding was due to a change in the affinity for the ligand or in the total number of binding sites, Scatchard analyses of saturation binding experiments were performed. As is seen in Figure 9, the decrease in binding after treatment with $30 \%$ RFCM for 2 weeks was due to a decrease in $B_{\max }$ from $3.41 \mathrm{pmol} / \mathrm{mg}$ protein to $1.98 \mathrm{pmol} /$ $\mathrm{mg}$ protein, with no significant change in $K_{\mathrm{d}}$ (control, $28.4 \mathrm{pM}$; RFCM, 35.9 pM).

Since neuron numbers were unchanged by treatment with RFCM, the observed changes in muscarinic binding did not

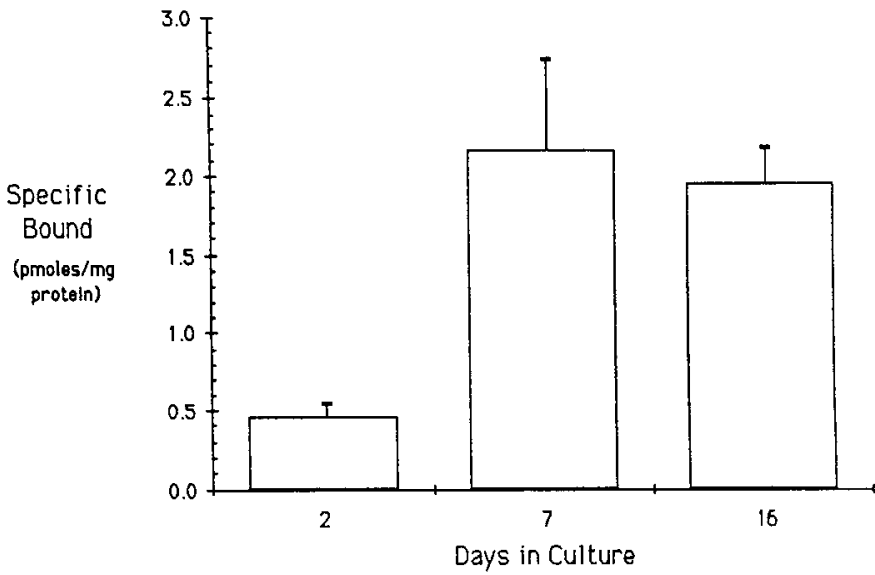

Figure 6. Development of ${ }^{3} \mathrm{H}-\mathrm{QNB}$ binding in cultured SCG neurons over time in culture. Sister SCG cultures were harvested after 2,7 , and $16 \mathrm{~d}$ and assayed for ${ }^{3} \mathrm{H}-\mathrm{QNB}$ binding. Bars represent mean $\pm \mathrm{SD}(n=$ 3).

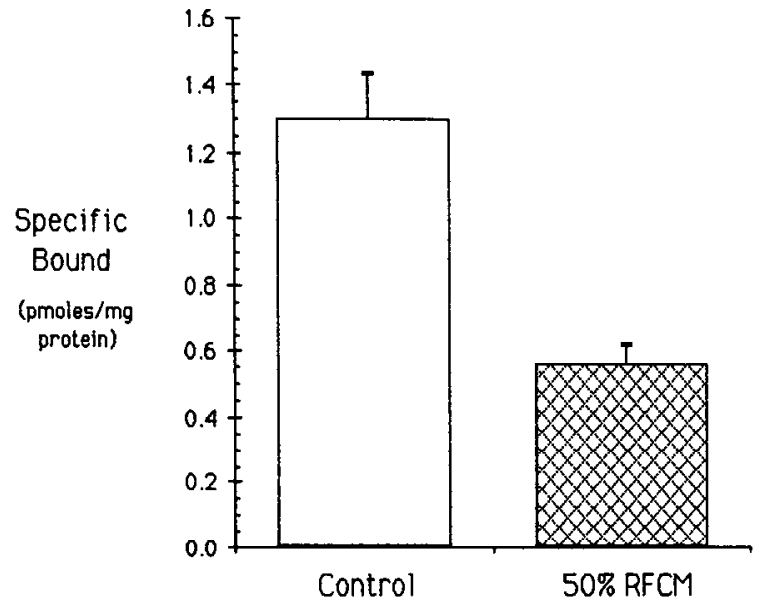

Figure 7. Effect of RFCM treatment of SCG cultures on $0.5 \mathrm{~nm}{ }^{3} \mathrm{H}-$ QNB binding. Cultures were grown for 2 weeks either in control medium or medium containing 50\% RFCM before harvesting for ${ }^{3} \mathrm{H}-\mathrm{QNB}$ binding. Bars represent mean $\pm \mathrm{SEM} ; n=3$. Binding to RFCM cultures differs from control at $p<0.01$ (2-tailed $t$ test). Neuron numbers were not significantly affected by the treatment.

reflect death of subpopulations of ncurons. However, to exclude the possibility that the reduction in QNB binding was due to a nonspecific toxic effect of RFCM, several other biochemical traits were examined. In agreement with previous reports (Patterson and Chun, 1977; Kessler, 1985) activity of the cholinergic biosynthetic enzyme (CAT) was greatly increased in cultures treated with 50\% RFCM, while activity of tyrosine hydroxylase, the rate-limiting enzyme in catecholamine biosynthesis, was unchanged (Table 1). RFCM treatment also caused large increases in levels of the neuropeptides somatostatin and substance $\mathrm{P}$, and in their respective mRNA levels (Kremer and Kessler, 1986; Spiegel et al., 1986). To control for the possibility that RFCM treatment nonselectively altered neuron membranes, we examined the binding of ${ }^{125} \mathrm{I}-\alpha-\mathrm{BTX}$. The SCG contains abundant $\alpha$-BTX binding sites that are not, however, functional receptors (Obata, 1974; Carbonetto et al., 1976; Ko et al., 1976; Brown and Fumagalli, 1977). If neuronal properties such

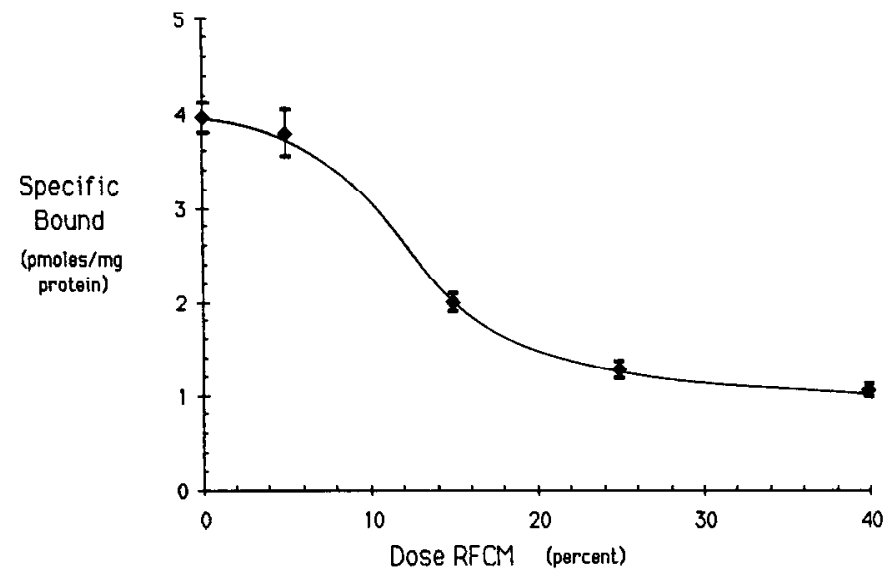

Figure 8. Dose-dependence of RFCM effect on ${ }^{3} \mathrm{H}-\mathrm{QNB}$ binding. SCG cultures were grown for 4 weeks with either control medium or medium mixed with RFCM at the indicated percentages. Cultures were harvested and assayed for binding of $0.5 \mathrm{~nm}{ }^{3} \mathrm{H}-\mathrm{QNB}$. Points represent mean \pm SD of one representative experiment. Each dose was repeated 1-3 times with similar results. 


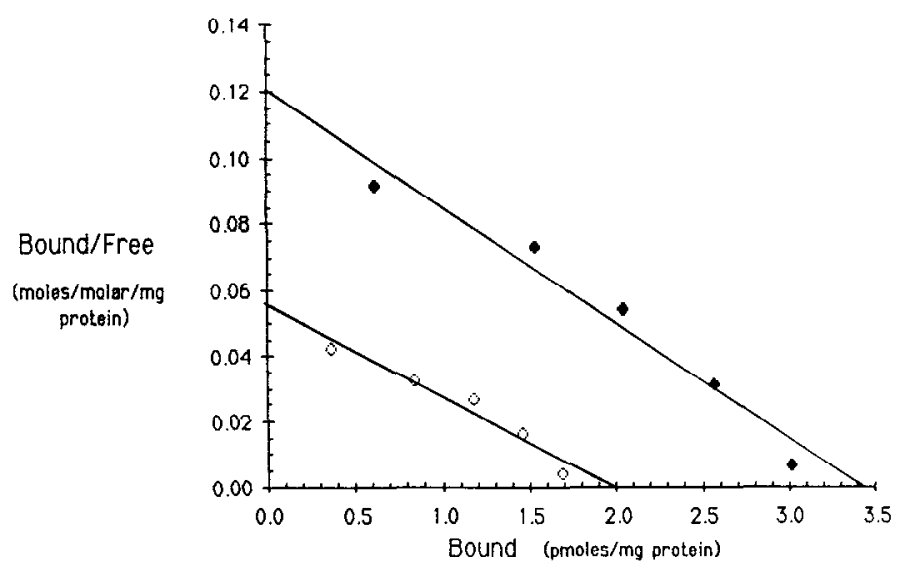

Figure 9. Scatchard analysis of RFCM effect on specific ${ }^{3} \mathrm{H}-\mathrm{QNB}$ binding. SCG cultures were grown with (open diamonds) or without (closed diamonds) $30 \%$ RFCM for 2 weeks before harvesting. ${ }^{3} \mathrm{H}-\mathrm{QNB}$ concentrations were from 0.01 to $0.50 \mathrm{nM}$. Control $K_{\mathrm{d}}=28.4 \mathrm{pM}, B_{\max }=$ $3.41 \mathrm{pmol} / \mathrm{mg}$ protein; RFCM $K_{\mathrm{d}}=35.9 \mathrm{pM}, B_{\text {max }}=1.98 \mathrm{pmol} / \mathrm{mg}$ protein. Graph shows one typical experiment (triplicate determinations) out of 3 performed.

as membrane surface area or neurite extension were altered by RFCM treatment, we would expect to see an alteration in $\alpha$-BTX binding sites. As shown in Figure 10, treatment of cultures with $30 \%$ RFCM had no significant effect on specific ${ }^{125} \mathrm{I}-\alpha$-BTX binding. Lower doses of RFCM also had no effect (data not shown). These findings demonstrate that RFCM treatment causes a spectrum of selective phenotypic changes, including increases in several specific transmitter systems, as well as a decrease in muscarinic receptor number.

Since CAT activity and acetylcholine synthesis (Patterson and Chun, 1977) are elevated by treatment with RFCM, the decrease in muscarinic binding could have reflected agonist-induced downregulation due to increased acetylcholine release, similar to the effect of carbachol shown in Figure 5. To determinc whether this mechanism mediated the change in QNB binding, experiments using atropine as a potential blocker were performed. Cultures were treated with either $10^{-5} \mathrm{M}$ carbachol or $15 \% \mathrm{RFCM}$ in the presence and absence of $10^{-6} \mathrm{M}$ atropine. As shown in Figure 11 , the $\sim 70 \%$ reduction in binding caused by carbachol was completely prevented by concurrent treatment with atropine, while atropine alone had no effect. By contrast, the $32 \%$ reduction in binding after RFCM treatment was not sensitive to atropine, indicating that muscarinic receptor activation by acetylcholine was not responsible for the effect.

Table 1. Effect of RFCM on CAT and TH enzyme activity ${ }^{a}$

\begin{tabular}{lllc} 
& $\begin{array}{l}\text { CAT activity } \\
\text { (pmol/min/ } \\
\text { neuron) }\end{array}$ & $\begin{array}{l}\text { TH activity } \\
\text { (fmol/min/ } \\
\text { neuron) }\end{array}$ & Neuron number \\
\hline Control & $0.88 \pm 0.21$ & $3.6 \pm 0.2$ & $10,180 \pm 190$ \\
$50 \%$ RFCM & $7.70 \pm 0.85^{b}$ & $3.2 \pm 0.3$ & $9990 \pm 210$
\end{tabular}

SCG cultures were treated with or without $50 \%$ RFCM for 2 weeks before harvesting. $\mathrm{CAT}$ and TH enzyme measurements were made at that time.

${ }^{a} \mathrm{TH}$, tyrosine hydroxylase.

${ }^{b}$ Values represent mean $\pm \mathrm{SEM}, n=8(p<0.001)$.

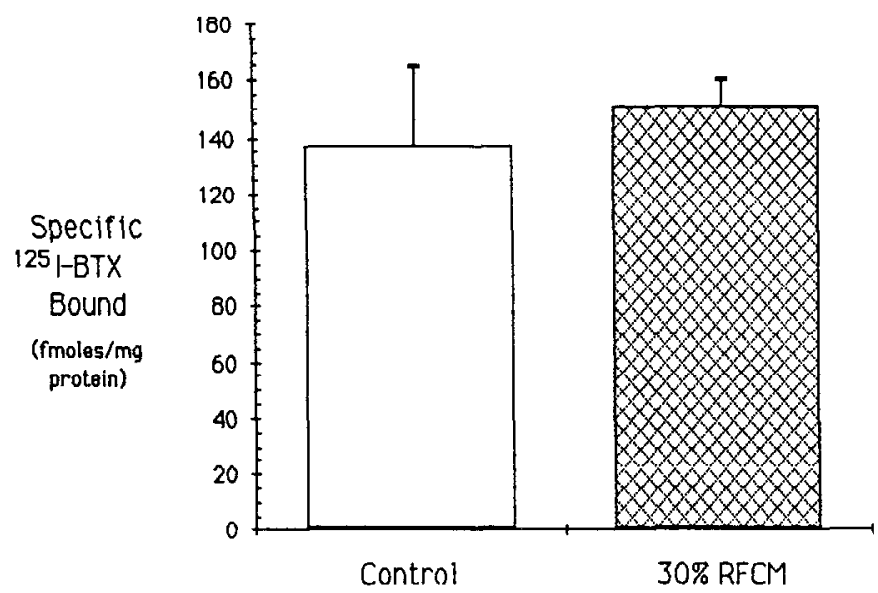

Figure 10. RFCM effect on ${ }^{125} \mathrm{I}-\alpha$-BTX binding to SCG neurons. Cultures were grown in control medium or medium containing $30 \% \mathrm{RFCM}$ for $16 \mathrm{~d}$ before harvesting. The ${ }^{125} \mathrm{I}-\alpha$-BTX binding assay was carried oul as described in Materials and Methods. Bars represent mean $\perp$ SD of triplicate determinations. Binding in the RFCM group was not significantly different from control.

\section{Discussion}

Membrane receptor systems may be regulated by the cellular microenvironment. For example, receptor numbers, as well as functional coupling to transduction systems, can be regulated by transmitter activation of receptors (Siman and Klein, 1981; Sibley et al., 1987). Moreover, CNS tissue produces soluble factors that increase numbers of acetylcholine receptors in muscle and sympathetic neurons, and that promote clustering of receptors (Jessell et al., 1979; Schaffner and Daniels, 1982; Leah et al., 1986). It is not known whether these factors are produced by the presynaptic neurons or by non-neuronal cells. Receptor numbers are also subject to hormonal regulatory influences. For example, glucocorticoids increase cholccystokinin rcceptor lcvels in cultured pancreatic acinar cells (Logsdon, 1986) and increase insulin receptor number in mouse fibroblasts (Knutson, 1986). Other potential regulatory factors include polypeptide growth

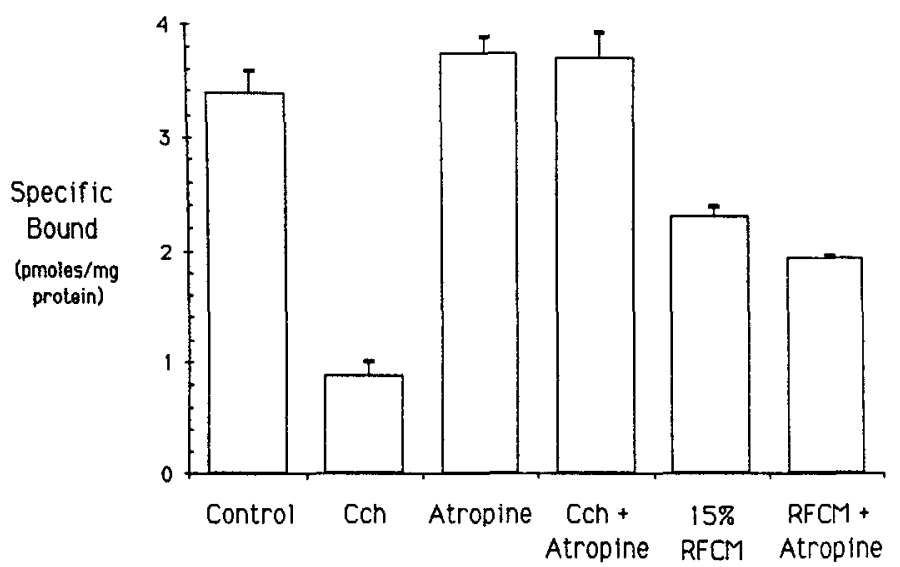

Figure 11. Effects of carbachol and RFCM in the presence of atropine. SCG cultures were treated for 2 weeks with either $10^{-5} \mathrm{M}$ carbachol or $15 \%$ RFCM in the absence and presence of $10^{-6} \mathrm{M}$ atropine. Cultures were harvested at that time for ${ }^{3} \mathrm{H}-\mathrm{QNB}$ binding. Bars represent mean \pm SD (triplicate) of one experiment. Each condition was replicated 1-2 times. 
factors (Askanas et al., 1985) and gangliosides (Berry-Kravis and Dawson, 1985). Thus, there are a large number of potential regulatory signals governing receptor development. The present study used a well-defined culture system with a relatively homogeneous population of neurons to begin to rigorously define mechanisms mediating influences of the environment on neuronal membrane receptors. Since transmitter development in cultured rat sympathetic neurons has been extensively investigated (Patterson, 1978; Black, 1982; Kessler, 1985), the present study facilitated comparison of the effects of the environment on both receptor and transmitter development.

\section{Muscarinic receptors in sympathetic neurons}

Sympathetic neurons in the SCG contain large numbers of both nicotinic and muscarinic receptors. Since the high-affinity muscarinic ligand ${ }^{3} \mathrm{H}-\mathrm{QNB}$ labeled receptors in cultured neurons at levels high enough to allow practical binding studies in culture, we examined muscarinic receptor development. Muscarinic receptors participate in the SCG response to input from preganglionic fibers in vivo. Preganglionic stimulation in the presence of nicotinic blocking agents results in slow postsynaptic potentials that are inhibited by muscarinic antagonists (Ashe and Yarosh, 1984). Direct activation of the receptors with muscarinic agonists alters sympathetic neuron membrane currents (Hashiguchi et al., 1982; Brown and Selyanko, 1985), increases inositol phosphate metabolism (Bone et al., 1984; Horwitz et al., 1986), and increases phosphorylation of tyrosine hydroxylase (Cahill and Perlman, 1985) in SCG neurons. Thus, muscarinic receptors influence several physiological functions of SCG neurons. Nevertheless, relatively little is known about the regulation of muscarinic receptors in the SCG. Preganglionic denervation of the SCG increased muscarinic receptor number in cats (Taniguchi et al., 1983), but had no effect in rats (Burt, 1978). By contrast, postganglionic axotomy diminished muscarinic rcceptor binding (Sinicropi ct al., 1979), suggesting that target-related factors may be important in regulating receptor number. NGF treatment of ganglion explants prevented a decrease in the muscarinic binding found in control cultures, which suggests that NGF could mediate some of the target-related effects on receptor number (Dombrowski et al., 1983). NGF treatment of PC12 pheochromocytoma cells increased muscarinic receptor binding (Jumblatt and Tischler, 1982). Agonistinduced down-regulation of muscarinic receptors has been well characterized in several systems (Siman and Klein, 1981; Champion and Mauchamp, 1982), as well as in this study (Fig. 5). Finally, glucocorticoid treatment did not alter muscarinic binding in SCG explants, suggesting that the hormone is not involved in regulating muscarinic receptor development in sympathetic neurons (Dombrowski et al., 1983).

In this study we found that cultures of dissociated sympathetic neurons had specific, saturable, high-affinity binding sites for ${ }^{3} \mathrm{H}$-QNB (Figs. 1, 2). Moreover, these sites exhibited pharmacologic specificity for muscarinic ligands, with higher affinity for the classical antagonist atropine than for agonists, as is commonly observed (Aguilar et al., 1982; Champion and Mauchamp, 1982; Jumblatt and Tischler, 1982; Watson et al., 1986). Multiple subtypes of muscarinic receptors were probably present, since inhibition of ${ }^{3} \mathrm{H}-\mathrm{QNB}$ binding by the selective $\mathrm{M} 1$ antagonist pirenzipine yielded a Hill coefficient of less than 1 . Using patch-clamp techniques in collaboration with Dr. D. Brosius, we observed muscarinic currents in the cultured sympathetic neurons (Brosius et al., 1986). In toto, these observations suggest that the ${ }^{3} \mathrm{H}-\mathrm{QNB}$ binding sites represent functional receptors, that the receptors in culture are similar to those in more intact systems, and that regulation of muscarinic receptors can be appropriately studied using dissociated neuron cultures of the SCG.

\section{Regulation of muscarinic receptors by non-neuronal cells}

Treatment of sympathetic neurons with RFCM significantly decreased ${ }^{3} \mathrm{H}-\mathrm{QNB}$ binding in a dose-dependent manner. Scatchard analysis of saturation curves demonstrated that the decrease in binding reflected a reduction in the total number of receptors rather than a change in the affinity for the ligand. By contrast, RFCM treatment had no effect on the binding of ${ }^{125} \mathrm{I}$ $\alpha$-BTX, demonstrating the selectivity of the effect on muscarinic binding. Moreover, treatment with RFCM increased neuronal levels of CAT (Table 1) and somatostatin, as previously reported (Patterson and Chun, 1977; Spiegel et al., 1986), indicating that stimulatory, as well as inhibitory, effects were exerted on neuronal phenotypic expression. The reduction in binding after RFCM treatment was unaffected by concurrent treatment with atropine, unlike the down-regulation due to carbachol, which was prevented by the antagonist. This suggests that a mechanism other than direct muscarinic receptor activation was responsible for the decrease in receptor number. Current studies are directed towards defining the precise mechanism underlying the effects of RFCM.

The prominent effects of RFCM on both transmitter expression and muscarinic receptor number suggest that transmitter and receptor development may be simultaneously regulated by the neuronal microenvironment. RFCM contains multiple proteins shed by fibroblasts, so it is not yet known whether the same molecule exerts effects on both transmitters and receptors. Nevertheless, it is clear that soluble factors produced by a single type of non-neuronal cell may regulate both transmitter and receptor devclopment. If both the presynaptic and postsynaptic neurons at a synapse were responsive to non-neuronal-derived soluble factors, then such factors could help coordinate the match between presynaptic neuronal expression of transmitter and postsynaptic neuronal receptor expression. Human, calf, and rat brains contain a factor similar or identical to the cholinergicpromoting factor in RFCM (Kessler et al., 1986); thus, neurons in the brain, as well as in the periphery, may be regulated by the factor. It is interesting that RFCM down-regulated muscarinic cholinergic receptors, but at the same time stimulated cholinergic transmitter expression. We are currently examining the effects of RFCM on other receptors, including nicotinic and substance $P$ receptors, to determine whether some of them are stimulated by the treatment.

\section{References}

Adler, J. E., and I. B. Black (1985) Sympathetic neuron density differentially regulates transmitter phenotypic expression in culture. Proc. Natl. Acad. Sci. USA 82: 4296-4300.

Aguilar, J. S., P. J. I. Salas, and E. deRobertis (1982) Cholinergic muscarinic receptor in synaptosomal membranes: Heterogeneity of binding sites for $\mathrm{L}-\left[{ }^{3} \mathrm{H}\right]$ quinuclidinyl benzilate. Mol. Pharmacol. 22 : 304-309.

Amy, C. M., and E. L. Bennett (1983) Increased sodium ion conductance through nicotinic acetylcholine receptor channels in PC12 cells exposed to nerve growth factors. J. Neurosci. 3: 1547-1553.

Ashe, J. H., and B. Libet (1982) Pharmacological properties and monoaminergic mediation of the slow IPSP, in mammalian sympathetic ganglion. Brain Res. 242: 345-349.

Ashe, J. H., and C. A. Yarosh (1984) Differential and selective an- 
tagonism of the slow-inhibitory postsynaptic potential and slow-excitatory postsynaptic potential by gallamine and pirenzipine in the superior cervical ganglion of the rabbit. Neuropharmacology 23: 13211329.

Askanas, V., S. Cave, G. Gallez-Hawkins, and W. K. Engel (1985) Fibroblast growth factor, epidermal growth factor and insulin exert a neuronal-like influence on acetylcholine receptors in aneurally cultured human muscle. Neurosci. Lett. 61: 213-219.

Ballanyi, K., and P. Grafe (1985) An intracellular analysis of $\gamma$-aminobutyric acid-associated ion movements in rat sympathetic neurons. J. Physiol. 365: 41-58.

Berry-Kravis, E., and G. Dawson (1985) Possible role of gangliosides in regulating an adenylate cyclase-linked 5-hydroxytryptamine $\left(5-\mathrm{HT}_{1}\right)$ receptor. J. Neurochem. 45: 1739-1747.

Black, I. B. (1982) Stages of ncurotransmittcr development in autonomic neurons. Science 215: 1198-1204.

Black, I., I. Hendry, and L. Iversen (1971) Transsynaptic regulation of growth and development of adrenergic neurons in a mouse sympathetic ganglion. Brain Res. 34: 228-240.

Bone, E. A., P. Fretten, S. Palmer, C. J. Kirk, and R. H. Michell (1984) Rapid accumulation of inositol phosphates in isolated rat superior cervical sympathetic ganglia exposed to $V_{1}$-vasopressin and muscarinic cholinergic stimuli. Biochem. J. 221: 803-811.

Bradford, M. (1976) A rapid and sensitive method for the quantitation of microgram quantities of protein utilizing the principle of proteindye binding. Anal. Biochem. 72: 248.

Brosius, D., J. A. Kessler, and D. C. Spray (1986) Substance P and its analogs interact and modify responses to nicotinic receptor agonists in rat sympathetic neurons. Soc. Neurosci. Abstr. 12: 34.

Brown, D. A., and M. P. Caulfield (1979) Hyperpolarizing " $\alpha_{2}$ "'-adrenoceptors in rat sympathetic ganglia. Br. J. Pharmacol. 65: 435445.

Brown, D. A., and P. M. Dunn (1983) Depolarization of rat isolated superior cervical ganglia mediated by $\beta_{2}$-adrenoceptors. Br. J. Pharmacol. 79: 429-439.

Brown, D. A., and L. Fumagalli (1977) Dissociation of $\alpha$-bungarotoxin binding and receptor block in the rat superior cervical ganglion. Brain Res. 129: 165-168.

Brown, D. A., and A. A. Selyanko (1985) Two components of muscarine-sensitive membrane current in rat sympathetic neurons. J. Physiol. (Lond.) 358: 335-363.

Brown, D. A., A. Forward, and S. Marsh (1980) Antagonist discrimination between ganglionic and ilcal muscarinic receptors. Br. J. Pharmacol. 71: 362-364.

Burt, D. R. (1978) Muscarinic receptor binding in rat sympathetic ganglion is unaffected by denervation. Brain Res. 143: 573-579.

Cahill, A. L., and R. L. Perlman (1985) Nicotinic and muscarinic agonists, phorbol esters, and agents which raise cyclic AMP levels phosphorylate distinct groups of proteins in the superior cervical ganglion. Neurochem. Res. 11: 327-338.

Carbonetto, S. T., D. M. Fambrough, and K. J. Muller (1976) Nonequivalence of $\alpha$-bungarotoxin receptors and acetylcholine receptors in chick sympathetic neurons. Proc. Natl. Acad. Sci. USA 75: 10161020.

Champion, S., and J. Mauchamp (1982) Muscarinic cholinergic receptors on cultured thyroid cells. II. Carbachol-induced desensitization. Mol. Pharmacol. 21: 73-77.

Cole, A. E., and P. Shinnick-Gallagher (1984) Muscarinic inhibitory transmission in mammalian sympathetic ganglia mediated by increased potassium conduclance. Nature 307: 270-271.

Dichter, M. A., A. S. Tischler, and L. A. Greene (1977) Nerve growth factor-induced increase in electrical excitability and acetylcholine sensitivity of a rat pheochromocytoma cell line. Nature 268: 501-504.

Dombrowski, A. M., A. A. Jenkins, and F. C. Kauffman (1983) Muscarinic receptor binding and oxidative enzyme activities in the adult rat superior cervical ganglion: Effects of 6-hydroxydopamine and nerve growth factor. J. Neurosci. 3: 1963-1970.

Fukada, K. (1980) Hormonal control of neurotransmitter choice in sympatheric neurone cultures. Nature 287: 553-555.

Harden, T. K., S. J. Foster, and J. P. Perkins (1979) Differential expression of components of the adenylate cyclasc systcm during growth of astrocytoma cells in culture. J. Biol. Chem. 254: 44164422 .

ILashiguchi, T., H. Kobayashi, T. Tosaka, and B. Libet (1982) Two muscarinic depolarizing mechanisms in mammalian sympathetic neurons. Brain Res. 242: 378-382.
IIorwitz, J., C. H. Anderson, and R. L. Perlman (1986) Comparison of the effects of muscarine and vasopressin on inositol phospholipid metabolism in the superior cervical ganglion of the rat. J. Pharmacol. Exp. Ther. 237: 312-317.

Ip, N. Y., and R. E. Zigmond (1984) Substance P inhibits the acute stimulation of ganglionic tyrosine hydroxylase activity by a nicotinic agonist. Neuroscience 13: 217-220.

Ip, N. Y., C. Baldwin, and R. E. Zigmond (1985) Regulation of the concentration of adenosine $3{ }^{\prime}-5^{\prime}$-cyclic monophosphate and the activity of tyrosine hydroxylase in the rat superior cervical ganglion by three neuropeptides of the secretin family. J. Neurosci. 5: 1947-1954.

Jessell, T. M., R. E. Siegel, and G. D. Fischbach (1979) Induction of acetylcholine receptor on cultured skeletal muscle by a factor extracted from serum and spinal cord. Proc. Natl. Acad. Sci. USA 76: 53975401.

Jumblatt, J. E., and A. S. Tischler (1982) Regulation of muscarinic ligand binding sites by nerve growth factor in PC12 phaeochromocytoma cells. Nature $297: 152-154$.

Kessler, J. A. (1985) Differential regulation of peptide and catecholamine characters in cultured sympathetic neurons. Neuroscience 15 : 827-839.

Kessler, J. A., and I. B. Black (1979) The role of axonal transport in the regulation of enzyme activity in sympathetic ganglia of adult rats. Brain Res. 171: 415-424.

Kessler, J. A., J. E. Adler, W. O. Bell, and I. B. Black (1983) Substance $\mathrm{P}$ and somatostatin metabolism in sympathetic and special sensory ganglia in vitro. Neuroscience 9: 309-318.

Kessler, J. A., J. E. Adler, G. M. Jonakait, and I. B. Black (1984) Target organ regulation of substance $P$ in sympathetic neurons in culture. Dev. Biol. 103: 71-79.

Kessler, J. A., G. Conn, and V. B. Hatcher (1986) Isolated plasma membranes regulate neurotransmitter expression and facilitate effects of a soluble brain cholinergic factor. Proc. Natl. Acad. Sci. USA 83: 3528-3532.

Kiraly, M., S. Audigier, E. Tribollet, C. Barberis, M. Dolivo, and J. J. Dreifuss (1986) Biochemical and electrophysiological evidence of functional vasopressin receptors in the rat superior cervical ganglion. Proc. Natl. Acad. Sci. USA 83: 5335-5339.

Knutson, V.P. (1986) The acute and chronic effects of glucocorticoids on insulin receptor and insulin responsiveness. Transient fluctuations in intracellular receptor level parallel transient fluctuations in responsiveness. J. Biol. Chem. 26: 10306-10312.

Ko, C.-P., H. Burton, and R. P. Bunge (1976) Synaptic transmission between rat spinal cord explants and dissociated superior cervical ganglion neurons in tissue culture. Brain Res. 117: 437-460.

Kouvelas, E. D., and L. A. Greene (1982) Development of muscarinic cholinergic receptors in chick embryo sympathetic ganglia. Dev. Neurosci. 5: 375-378.

Kremer, N. E., and J. A. Kessler (1986) Regulation of substance P, substance $\mathrm{K}$, and their mRNAs in the superior cervical ganglion. Soc. Neurosci. Abstr. 12: 379.

Leah, J. D., E. Gipps, and C. Kidson (1986) Synapse formation and induction of acetylcholine receptors by spinal neurons in cocultures with sympathetic ganglion and muscle cells. Dev. Neurosci. 8: 7688.

Logsdon, C. D. (1986) Glucocorticoids increase cholecystokinin receptors and amylase secretion in pancreatic acinar AR42J cells. J. Biol. Chem. 261: 2096-2102.

McLennan, I., S. Hill, and I. A. Hendry (1980) Glucocorticoids modulate transmitter choice in developing superior cervical ganglion. Nature 283: 206-207.

Mobley, W. C., A. Schenker, and E. M. Shooter (1976) Characterization and isolation of proteolytically modified nerve growth factor. Biochemistry 15: 5543-5551.

Munson, P. J., and R. D. Rodbard (1980) LIGAND: A versatile computerized approach for characterization of ligand binding systems. Anal. Biochem. 107: 220-239.

Nakamura, T., Y. Nakayama, and A. Ichihara (1984) Acquisition of a $\beta$-adrenergic response by adult rat hepatocytes during primary culture. J. Biol. Chem. 259: 8056-8058.

Nathanson, N. M. (1983) Binding of agonist and antagonists to muscarinic acetylcholine receptors on intact cultured heart cells. J. Neurochem. 41: 1545-1549.

Niwa, M., K. Shigematsu, L. Plunkett, and J. M. Saavedra (1985) High-affinity substance $\mathrm{P}$ binding sites in rat sympathetic ganglia. Am. J. Physiol. 249: H694-H697. 
Obata, K. (1974) Transmitter sensitivities of some nerve and muscle cells in culture. Brain Res. 73: 171-188.

Patterson, P. H. (1978) Environmental determination of autonomic neurotransmitter functions. Annu. Rev. Neurosci. 1: 1-17.

Patterson, P. H., and L. Y. Chun (1977) The induction of acetylcholine synthesis in primary cultures of dissociated rat sympathetic neurons. 1. Effects of conditioned medium. Dev. Biol. 56: 263-280.

Pochet, R. P., D. A. Green, J. J. Goka, R. B. Clark, R. Barber, J. E. Dumont, and R. W. Butcher (1982) $\beta$-Adrenergic receptors and cyclic AMP responses to epinephrine in cultured human fibroblasts at various population densities. J. Cyclic. Nucleotide Res. 8: 83-84.

Schaffner, A. F., and M. P. Daniels (1982) Conditioned medium from cultures of embryonic neurons contains a high molecular weight factor which induces acetylcholine aggregation on cultured myotubes. J. Neurosci. 2: 623-632.

Sibley, D. R., and R. J. Lefkowitz (1985) Molecular mechanisms of receptor desensitization using the $\beta$-adrenergic receptor-coupled adenylate cyclase system as a model. Nature 317: 124-129.

Sibley, D. R., J. L. Benovic, M. G. Caron, and R. J. Lefkowitz (1987) Regulation of transmembrane signaling by receptor phosphorylation. Cell 48: 913-922.

Siman, R. G., and W. L. Klein (1981) Specificity of muscarinic acetylcholine receptor for regulation by receptor activity. J. Neurosci. 37: 1099-1108.

Sinicropi, D. V., F. C. Kauffman, and D. R. Burt (1979) Axotomy in rat sympathctic ganglia: Reciprocal effects on muscarinic receptor binding and 6-phosphogluconate dehydrogenase activity. Brain Res. 161: 560-565.

Spiegel, K., N. E. Kremer, and J. A. Kessler (1986) Differential regulation of somatostatin gene transcription in central and peripheral neurons in culture. Soc. Neurosci. Abstr. 12: 379.

Sze, P. Y., and B. J. Hedrick (1983) Effects of dexamethasone and other glucocorticoid steroids on tyrosine hydroxylase activity in the superior cervical ganglion. Brain Res. 265: 81-86.

Taniguchi, T., K. Kurahashi, and M. Fujiwara (1983) Alterations in muscarinic cholinergic receptors after preganglionic denervation of the superior cervical ganglion in cats. J. Pharmacol. Exp. Ther. 224: 674-678.

Walicke, P., R. Camperot, and P. Patterson (1977) Determination of transmitter function by neuronal activity. Proc. Natl. Acad. Sci. USA 74: 5767-5771.

Watson, M., H. I. Yamamura, and W. R. Roeske (1986) [ $\left.{ }^{3} \mathrm{H}\right]$ Pirenzipine and $(-)-\left[{ }^{3} \mathrm{H}\right]$ quinuclidinyl benzilate binding to rat cerebral cortical and cardiac muscarinic cholinergic sites. I. Characterization and regulation of agonist binding to putative muscarinic subtypes. J. Pharmacol. Exp. Ther. 237: 411-418.

Wong, V., and J. A. Kessler (1987) Solubilization of a membrane factor that stimulates levels of substance $P$ and choline acetyltransferase in sympathetic neurons. Proc. Natl. Acad. Sci. USA 84: 87268729. 